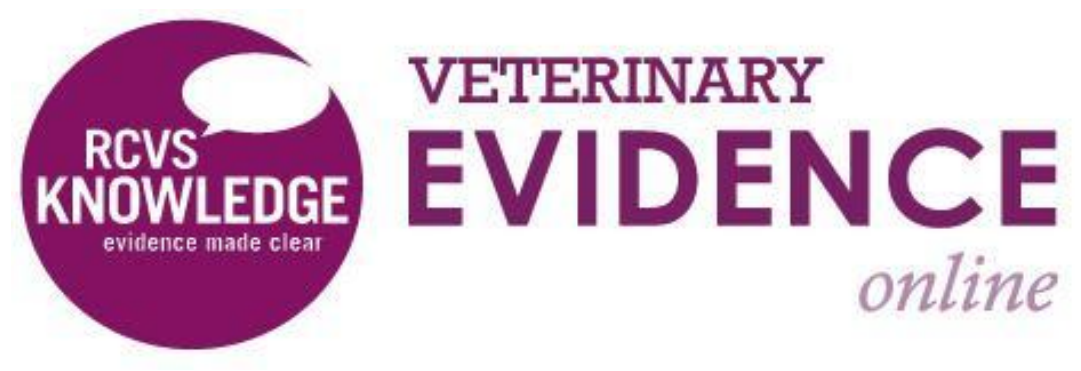

\title{
In Adult Horses With Septic Peritonitis, Does \\ Peritoneal Lavage Combined With Antibiotic Therapy Compared to Antibiotic Therapy Alone Improve Survival Rates?
}

\section{A Knowledge Summary by}

Sarah Scott Smith MA, VetMB, MVetMed, DipACVIM, MRCVS, RCVS ${ }^{{ }^{*}}$

${ }^{1}$ Equine Referral Hospital, Langford Veterinary Services, Langford, BS40 5DU

Corresponding Author (sarah1.smith@bristol.ac.uk)

ISSN: 2396-9776

Published: 13 Nov 2017

in: Vol 2, Issue 4

DOI: http://dx.doi.org/10.18849/ve.v2i4.135

Reviewed by: Kate McGovern (BVetMed, CertEM(Int.Med), MS, DACVIM, DipECEIM, MRCVS) and Cathy McGowan (BVSC, MACVS, DEIM, Dip ECEIM, PhD, FHEA, MRCVS) 


\section{KNOWLEDGE SUMMARY}

\section{Clinical bottom line}

The quality of evidence in equids is insufficient to direct clinical practice aside from the following:

The use of antiseptic solution to lavage the abdomen causes inflammation and is detrimental to the patient.

For peritonitis caused by Actinobacillus equuli, treatment with antibiotics alone may be sufficient. A variety of antibiotics were used in the two reported studies.

\section{Question}

In adult horses with septic peritonitis, does peritoneal lavage combined with antibiotic therapy compared to antibiotic therapy alone improve survival rates?

\section{The Evidence}

There is a small quantity of evidence and the quality of the evidence is low, with comparison of the two treatment modalities in equids only performed in case series. There is a single study which performed the most robust analysis possible of a retrospective case series by using multivariate analysis to examine the effect of multiple variables on survival (Nogradi et al., 2011). Inherent to case series is the risk that case selection will have introduced significant bias into the results; peritoneal lavage maybe used more commonly in more severely affected cases or where the abdomen has been contaminated with intestinal or uterine contents. There have been no randomised trials to compare the efficacy of the treatment options discussed.

When examining the method of peritoneal lavage chosen there is a single experimental, randomised control trial comparing the use of sterile saline, saline containing potassium penicillin and neomycin, $3 \%$ or $10 \%$ povidone iodine solution for abdominal lavage in horses. The quality of evidence describing types of antibiotics used is low (case series) and there is no direct comparison of antibiotics used.

\section{Summary of the evidence}

\begin{tabular}{l} 
Golland (1994) \\
\hline \\
$\qquad$\begin{tabular}{ll|}
\hline Population: & Horses with peritonitis attributed to Actinobacillus equuli at one \\
Australian equine hospital \\
$1982-1992$ \\
Excluded: post-operative peritonitis \\
Peritonitis: not defined
\end{tabular} \\
\hline Sample size: 15 \\
\hline
\end{tabular}




\begin{tabular}{|c|c|}
\hline Intervention details: & $\begin{array}{l}\text { 1. Antibiotics: } n=15 \text { (procaine penicillin and neomycin [ } n=12] \text {, } \\
\text { procaine penicillin and gentamicin }[n=1] \text {, trimethoprim } \\
\text { sulfadiazine }[n=1] \text {, oxytetracycline then trimethoprim } \\
\text { sulphadiazine }[n=1] \text { ) } \\
\text { 2. Abdominal lavage: } 1 / 15 \text { (3l balanced polyionic solution + } \\
\text { 3g benzyl penicillin q } 12 h \text { ) }\end{array}$ \\
\hline \multicolumn{2}{|c|}{ Study design:Case series } \\
\hline Outcome studied: & $\begin{array}{l}\text { - } \text { Clinical improvement after } 48 \mathrm{~h} \text { of treatment } \\
\text { - } \quad \text { Survival rate }\end{array}$ \\
\hline $\begin{array}{r}\text { Main findings: } T \\
\text { (relevant to PICO question): } S\end{array}$ & $\begin{array}{l}\text { ere was a rapid response to antibiotic treatment and high } \\
\text { vival rate of peritonitis caused by } A \text {. equuli infection } \\
\text { - } \quad \text { Clinical improvement after } 48 \mathrm{~h}: 15 / 15 \\
\text { breeding) } \\
\text { - } \quad \text { information not available for } 3 / 15, \\
\text { - } \\
\text { euthanised for unrelated condition } 1 / 15\end{array}$ \\
\hline Limitations: & $\begin{array}{l}\text { - Small sample size } \\
\text { - } \quad \text { Abdominal lavage was only performed in one case and } \\
\text { there was no comparison of treatment protocols } \\
\text { - Survival information was not available for } 3 / 15 \text { cases } \\
\text { - Neomycin is rarely used in current clinical practice }\end{array}$ \\
\hline
\end{tabular}

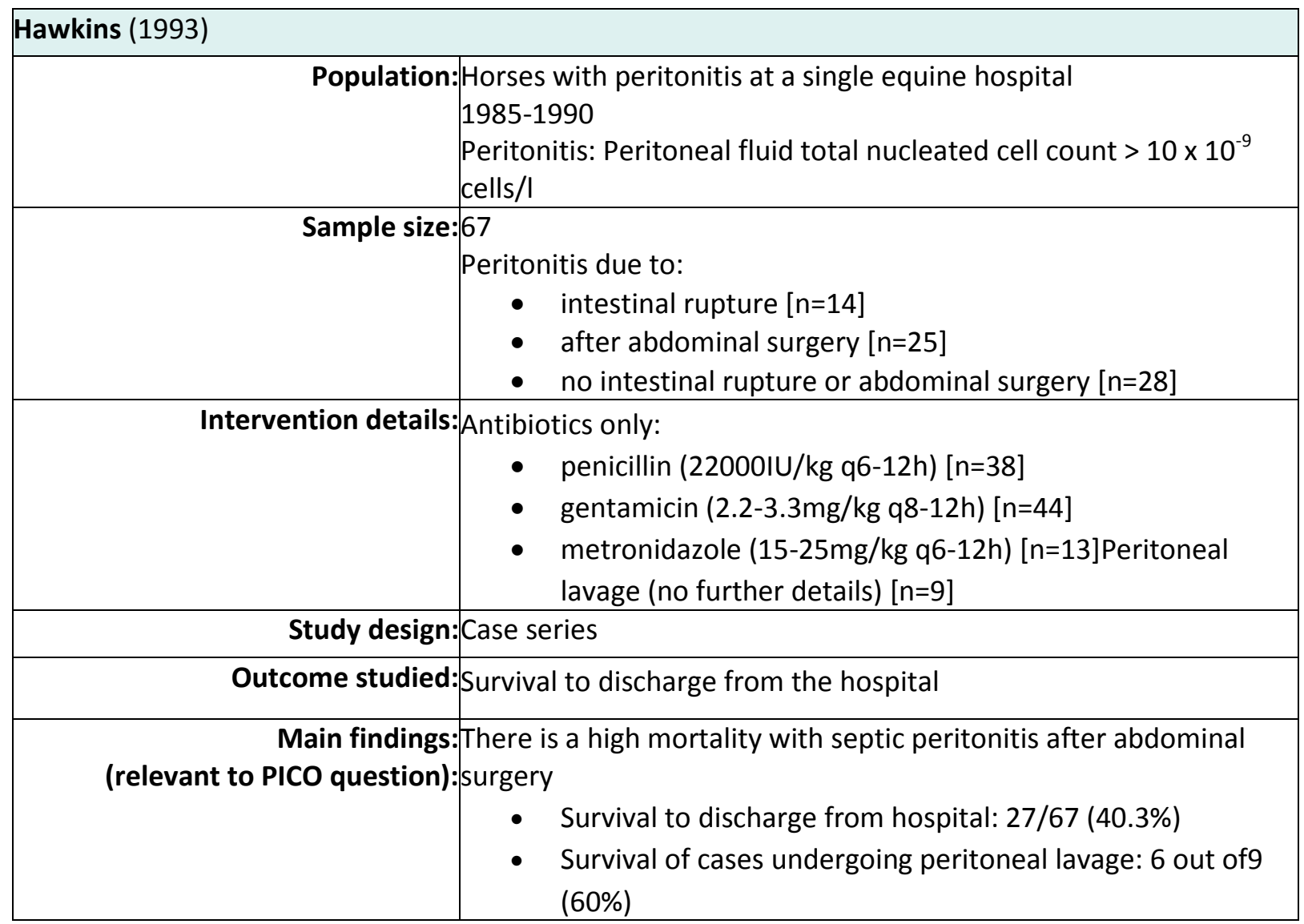




\begin{tabular}{|l|cc|}
\hline Limitations: & $\begin{array}{c}- \\
\text { No details of substance, volume, frequency of }\end{array}$ \\
- & Very limited details of other treatments given \\
- & No statistical comparison of interventions \\
hospital & No follow-up of survival after discharge from the \\
- & The dosing regime of gentamicin is not consistent \\
with that used in current clinical practice
\end{tabular}

\begin{tabular}{|c|c|}
\hline \multicolumn{2}{|l|}{ Henderson (2008) } \\
\hline \multicolumn{2}{|c|}{ 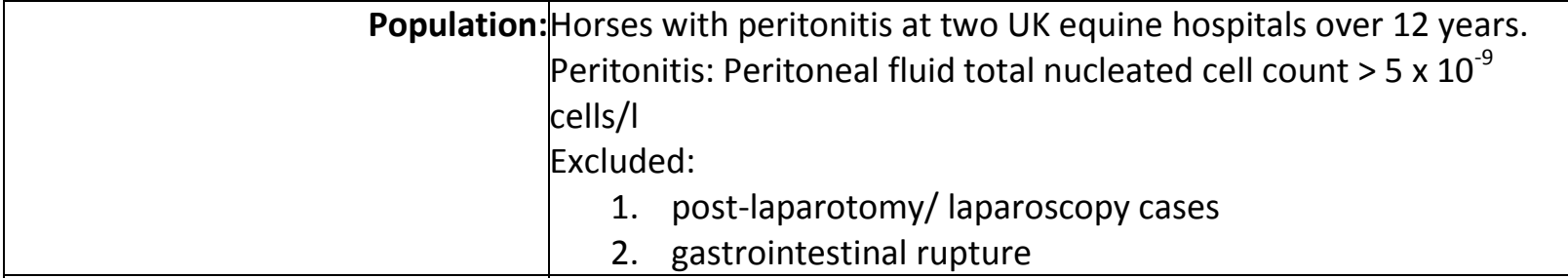 } \\
\hline Sample size: $\left[\begin{array}{l}6 \\
T \\
\text { ic } \\
\text { M }\end{array}\right.$ & $\begin{array}{l}\text { The effect of treatment was compared for } 50 \text { horses with } \\
\text { idiopathic peritonitis. } 15 \text { horses with identified causes of peritonitis } \\
\text { were excluded from treatment comparison. }\end{array}$ \\
\hline Intervention details: & $\begin{array}{l}\text { - Broad-spectrum antibiotics (no further details provided) } \\
\text { [ } n=56] \text {, with anthelmintics [ } n=7] \\
\text { Peritoneal lavage [ } n=9] \text { via exploratory laparotomy }[n=5] \text { or } \\
\text { standing drain placement }[n=4]\end{array}$ \\
\hline \multicolumn{2}{|c|}{ Study design:Case series } \\
\hline Outcome studied: & $\begin{array}{ll}\text { - } & \text { Survival } \\
\text { - } & \text { Development of complications }\end{array}$ \\
\hline \multicolumn{2}{|c|}{$\begin{array}{l}\text { Main findings: } 84 \% \text { of cases survived to } 12 \text { months. } \\
\text { (relevant to PICO question): } \\
\text { There was no association of treatment method with outcome or } \\
\text { complication rate. }\end{array}$} \\
\hline Limitations: & $\begin{array}{l}\text { Few details of treatment methods including type of } \\
\text { antimicrobials and solution used/ frequency of abdominal } \\
\text { lavage. } \\
\text { idiopathic peritonitis how many horses there were in each } \\
\text { treatment group or the outcome of each treatment group }\end{array}$ \\
\hline
\end{tabular}

\begin{tabular}{|l|}
\hline Javsicas (2010) \\
\hline Population: \\
$\qquad \begin{array}{l}\text { Post-partum mares (within } 7 \text { days of foaling) with peritonitis or a } \\
\text { confirmed uterine tear treated at two equine hospitals } \\
1990-2007 \\
\text { Peritonitis: Peritoneal fluid total nucleated cell count }>10 \times 10^{-9} \\
\text { cells/l, total protein concentration }>2.5 \mathrm{~g} / \mathrm{dL}, \text { predominance of } \\
\text { degenerative neutrophils }+/ \text { - intracellular bacteria on cytological } \\
\text { examination } \\
\text { Excluded: vaginal laceration, gastrointestinal rupture, death on day } \\
\text { of admission }\end{array}$ \\
\hline Sample size: 49
\end{tabular}




\begin{tabular}{|c|c|}
\hline Intervention details: & $\begin{array}{l}\text { Medical }[n=15] \text {; antibiotic therapy } \\
\text { Surgical }[n=34] \text {; ventral midline coeliotomy } \\
\text { Abdominal lavage was performed in both groups and frequency of } \\
\text { abdominal lavage was not different between the treatment groups }\end{array}$ \\
\hline \multicolumn{2}{|c|}{ Study design: Case series } \\
\hline \multicolumn{2}{|c|}{ Outcome studied:Survival to discharge } \\
\hline \multicolumn{2}{|c|}{$\begin{array}{l}\text { Main findings: } \begin{array}{l}\text { Overall survival to discharge: } 76 \% \\
\text { (relevant to PICO question): } \\
\text { Survival was not different between medically (11 out } 15 \text { survived) } \\
\text { and surgically treated ( } 26 \text { out of } 34 \text { survived) cases. } \\
\text { Use of peritoneal lavage was not different between survivors and } \\
\text { non-survivors }\end{array} \\
\end{array}$} \\
\hline Limitations: & $\begin{array}{l}\bullet \quad \text { No definitive diagnosis of uterine tear in } 7 / 11 \\
\text { surviving medically treated cases } \\
\bullet \quad \text { No details of peritoneal lavage treatment or } \\
\text { antibiotics used }\end{array}$ \\
\hline & - $\quad$ No follow up information beyond discharge \\
\hline
\end{tabular}

\begin{tabular}{|c|c|}
\hline \multicolumn{2}{|l|}{ Matthews (2001) } \\
\hline Population: & $\begin{array}{l}\text { Horses with peritonitis attributed to Actinobacillus equuli seen at } \\
\text { one Australian equine hospital } \\
\text { 1993-1999 } \\
\text { Peritonitis: not defined }\end{array}$ \\
\hline \multicolumn{2}{|c|}{ Sample size:51 } \\
\hline Intervention details: & $\begin{array}{l}\text { - Antibiotic treatment (procaine penicillin } 20 \mathrm{mg} / \mathrm{kg} \text { IV BID } \\
{[\mathrm{n}=31], \text { procaine penicillin andgentamicin sulphate }} \\
6.6 \mathrm{mg} / \mathrm{kg} \text { IV SID [n=20] for } 5-14 \mathrm{~d} \text {, followed by } \\
\text { trimethoprim sulphonamide } 5 \mathrm{mg} / \mathrm{kg} \text { for } 2 \text { weeks [n=6]) } \\
\text { - Abdominal drain }[\mathrm{n}=2]\end{array}$ \\
\hline \multicolumn{2}{|c|}{ Study design: Case series } \\
\hline \multicolumn{2}{|c|}{ Outcome studied:Clinical improvement } \\
\hline \multicolumn{2}{|c|}{$\begin{array}{l}\text { Main findings:All horses survived to discharge and were clinically normal at the } \\
\text { (relevant to PICO question): time of discharge }\end{array}$} \\
\hline Limitations: & $\begin{array}{l}\text { No description of use of abdominal drain; it is unclear whether the } \\
\text { abdomen was lavaged or a drain placed without lavage. No } \\
\text { comparison of interventions } \\
\text { No follow up beyond discharge from the hospital }\end{array}$ \\
\hline
\end{tabular}

\begin{tabular}{|c|c|}
\hline \multicolumn{2}{|l|}{ Nieto (2003) } \\
\hline & $\begin{array}{l}\text { Population: } \begin{array}{l}\text { Horses at a single equine hospital treated with a closed negative } \\
\text { suction drainage system } \\
1989-1996 \\
\text { Patients included had abdominal surgery }[n=54], \text { reproductive } \\
\text { abnormalities }[n=7] \text { or peritonitis (peritoneal fluid total nucleated } \\
\text { cell count }>10 \times 10^{-9} \text { cells/l) }[n=6]\end{array}\end{array}$ \\
\hline & Sample size:67 \\
\hline
\end{tabular}




\begin{tabular}{|c|c|}
\hline Intervention details: & $\begin{array}{l}\text { - Abdominal lavage [ } n=66] \text { with lactated Ringer's solution or } \\
\text { saline containing; heparin [ } n=39] \text {, potassium penicillin } G \\
{[n=7] \text { or aminoglycosides }[n=16] \text { or } 0.1 \% \text { povidone iodine }} \\
\text { [ } n=2] \text {. No lavage [ } n=1] \\
\text { - Closed negative suction drain system [ } n=67] \\
\text { Systemic antibiotic therapy (combination of beta-lactam } \\
\text { antibiotic and aminoglycoside in } 60 \% \text { cases, the remainder } \\
\text { were given an additional antibiotic) }\end{array}$ \\
\hline \multicolumn{2}{|c|}{ Study design: Case series } \\
\hline Outcome studied: & $\begin{array}{l}\text { Volume of fluid retrieved } \\
\text { Complications } \\
\text { Survival to discharge from the hospital and long-term }\end{array}$ \\
\hline $\begin{array}{r}\text { Main findings: } \\
\text { (relevant to PICO question): }\end{array}$ & $\begin{array}{l}\text { - On average } 83 \% \text { of lavage fluid was retrieved } \\
\text { - Complications reported in } 49 \% \text { included obstruction of } \\
\text { drain, leakage of fluid/omental migration through the } \\
\text { abdominal wall after drain removal, pain, structural } \\
\text { damage to drain, haematoma formation around drain. } \\
\text { Incisional suppuration occurred in } 32 \% \text { of surgical cases } \\
\text { and } 5 \text { developed an incisional hernia. } \\
\text { - Survival to discharge from the hospital: } 93 \% \\
\text { - Long-term survival: } 78 \% \text { survived }>7 \text { months. Death was } \\
\text { due to colic }(n=4) \text {, laminitis }(n=3) \text {, adhesions }(n=3) \text {, } \\
\text { peritonitis }(n=1)\end{array}$ \\
\hline \multicolumn{2}{|c|}{$\begin{array}{l}\text { Limitations: } \\
\qquad \begin{array}{l}\text { No comparator group } \\
\text { states } \\
\text { Several different disease states were included making comparison } \\
\text { of treatment outcomes difficult } \\
0.1 \% \text { povidone iodine solution was used for lavage. } 3 \% \text { and } 10 \% \\
\text { povidone iodine solution has previously been shown to cause } \\
\text { inflammation (Schneider et al., 1988) }\end{array} \\
\end{array}$} \\
\hline
\end{tabular}

\begin{tabular}{|c|c|}
\hline \multicolumn{2}{|l|}{ Nogradi (2011) } \\
\hline \multicolumn{2}{|c|}{$\begin{array}{l}\text { Population: } \begin{array}{l}\text { Horses with peritonitis } \\
2004-2007 \\
\text { Peritonitis: peritoneal fluid total nucleated cell count }>10 \times 10^{-9} \\
\text { cells } / \mathrm{l} \text { or total protein concentration }>25 \mathrm{~g} / \mathrm{l} .\end{array}\end{array}$} \\
\hline \multicolumn{2}{|c|}{ Sample size: 55} \\
\hline Intervention details: & $\begin{array}{l}\text { - Non-surgical: Abdominal lavage }[\mathrm{n}=21] ; 1-4 \mathrm{x} / \text { daily with } \\
\text { polyionic crystalloid solution by gravity flow for } 1-12 \\
\text { days.Antibiotic therapy } \\
\text { - Surgical: Exploratory laparotomy [n=26] }\end{array}$ \\
\hline \multicolumn{2}{|c|}{ Study design:Case series } \\
\hline \multicolumn{2}{|c|}{$\begin{aligned} \text { Outcome studied: } & \text { Survival rate } \\
& \text { Factors associated with survival }\end{aligned}$} \\
\hline
\end{tabular}




\begin{tabular}{|c|c|}
\hline $\begin{array}{l}\text { Main findings } \\
\text { (relevant to PICO question) }\end{array}$ & 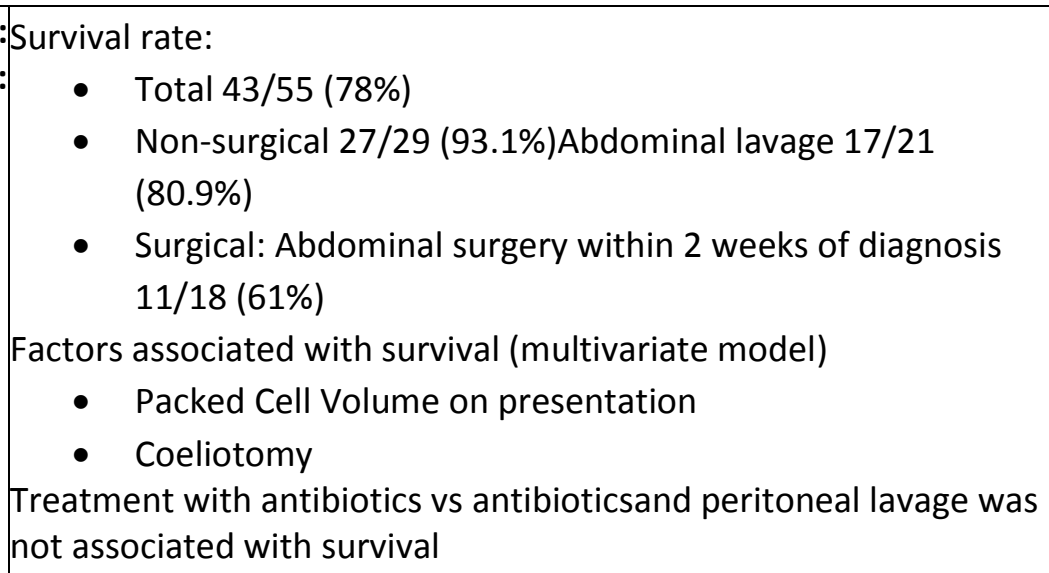 \\
\hline Limitations & $\begin{array}{l}\text { Duration of survival was not defined } \\
\text { Limited details of antibiotic treatment protocols are described } \\
\text { The statistical details of the comparison of antibiotics vs antibiotics } \\
\text { and peritoneal lavage is not provided. }\end{array}$ \\
\hline
\end{tabular}

\begin{tabular}{|c|c|}
\hline \multicolumn{2}{|l|}{ Schneider (1988) } \\
\hline \multicolumn{2}{|c|}{ Population: Healthy, adult ponies } \\
\hline \multicolumn{2}{|c|}{ Sample size: 24} \\
\hline Intervention details: $\mathrm{F}$ & $\begin{array}{l}\text { Peritoneal lavage performed once with } 20 \text { of: } \\
\text { 1. sterile saline }(0.9 \% \mathrm{NaCl})[\mathrm{n}=6] \\
\text { 2. sterile saline containing } 5 \times 10^{6} \mathrm{U} \text { of potassium penicillin } \\
\text { and } 3 g \text { neomycin [ } \mathrm{n}=6] \\
\text { 3. Povidone-iodine diluted to } 3 \% \text { with sterile saline }[\mathrm{n}=6] \\
\text { 4. Povidone-iodine diluted to } 10 \% \text { with sterile saline }[\mathrm{n}=3] \\
\text { Control population: } \\
\text { 5. Lavage catheter placed, no fluid instilled }[\mathrm{n}=3]\end{array}$ \\
\hline \multicolumn{2}{|c|}{ Study design: Randomised controlled trial } \\
\hline Outcome studied: & $\begin{array}{l}\text { - } \text { Clinical response (pain) } \\
\text { - Peritoneal fluid nucleated cell count, cytology, protein } \\
\text { concentration } \\
\text { - } \quad \text { Peritoneal cavity at necropsy } \\
\text { - Survival to } 96 \mathrm{~h}, \text { at which time all ponies were euthanised } \\
\text { for post mortem examination }\end{array}$ \\
\hline
\end{tabular}




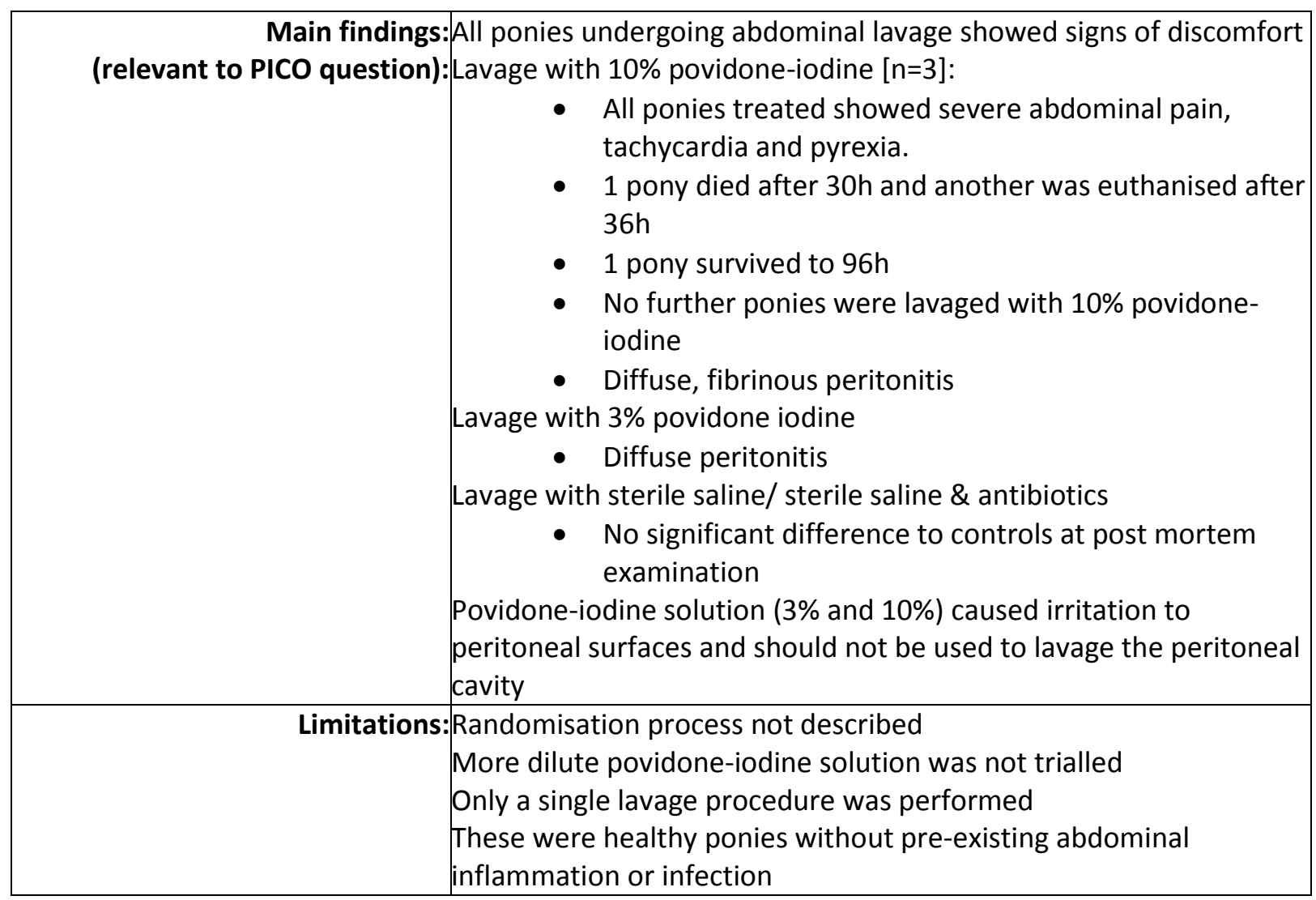

\section{Appraisal, application and reflection}

Only low-quality evidence is available comparing the use of antibiotics with the combined use of antibiotics and peritoneal lavage to treat horses with peritonitis. There are many likely confounding factors in the case series reported which are inherent to use of case series. This includes unblinded treatment selection; it is likely that more severely affected cases or those where the abdomen is contaminated with gastrointestinal or uterine contents are treated with peritoneal lavage and antibiotics whereas those thought to be less severely affected are treated with antibiotics alone. There is also significant variation in the treatments used between cases within studies and between studies, including the use of treatment protocols which are now outdated, in particular, aminoglycoside choice, dose and frequency, (Golland et al., 1994, Hawkins et al., 1993). There is variation in the class of antibiotics, doses and frequency used and duration of treatment for cases within and between studies. A single study (Nieto et al., 1993) included patients in which abdominal lavage was performed using povidone-iodine solution, which has been shown to cause peritoneal inflammation (Schneider et al., 1988) and several studies do not describe the fluid used for lavage the abdomen (Hawkins et al., 1993, Henderson et al., 2008, Javsicas et al., 2010, Matthews et al., 2001). Financial constraints may have influenced the choice of treatment and the survival of patients reported. Patients in all the case series studies described received additional treatments including intravenous fluid therapy, non-steroidal antiinflammatory medication, gastroprotectants, anti-endotoxic medication and prokinetics. The impact of these treatments was not analysed in most studies and is not described in this summary.

\section{Conclusion:}

There is no evidence in equids that there is a difference in survival when the use of antibiotics is compared to the use of antibiotics combined with peritoneal lavage. However, the quality of data available is insufficient to direct clinical practice apart from two areas; in peritonitis caused by Actinobacillus equuli, treatment with antibiotics alone is sufficient, and the use of antiseptic solutions such as povidone iodine to lavage the abdomen causes inflammation and is detrimental to the patient. More definitive conclusions cannot be drawn until higher quality evidence on this topic is available. 


\begin{tabular}{|c|c|}
\hline \multicolumn{2}{|l|}{ Search Strategy } \\
\hline Databases searched and dates & CAB Abstracts on OVID Platform 1973- Week 172017 \\
\hline covered: & PubMed accessed via the NCBI website 1973- Week 172017 \\
\hline Search terms: & $\begin{array}{l}\text { 1. (equine or horse or equus or colt or equid) and peritonitis) } \\
\text { 2. (antibiotic or antimicrobial or antibacterial or anti-microbial) } \\
\text { 3. (lavage OR surgery OR exploratory laparotomy OR } \\
\text { laparotomy OR coeliotomy OR celiotomy) } \\
\text { 4. } 1 \text { and ( } 2 \text { or } 3 \text { ) }\end{array}$ \\
\hline Dates searches performed: & $11^{\text {th }}$ May 2017 \\
\hline
\end{tabular}

\begin{tabular}{|c|c|}
\hline \multicolumn{2}{|l|}{ Exclusion / Inclusion Criteria } \\
\hline Exclusion: & $\begin{array}{l}\text { Non-English language papers } \\
\text { Single case reports } \\
\text { Book chapters and literature reviews without novel information } \\
\text { Not relevant to the question }\end{array}$ \\
\hline Inclusion: & $\begin{array}{l}\text { Papers comparing the use of antimicrobials with the combination } \\
\text { of antimicrobials and peritoneal lavage were included. Due to the } \\
\text { very limited available literature papers describing the use of } \\
\text { antimicrobials or antimicrobials and peritoneal lavage or peritoneal } \\
\text { lavage were included even when there was not a direct comparison } \\
\text { of treatment modalities. }\end{array}$ \\
\hline
\end{tabular}

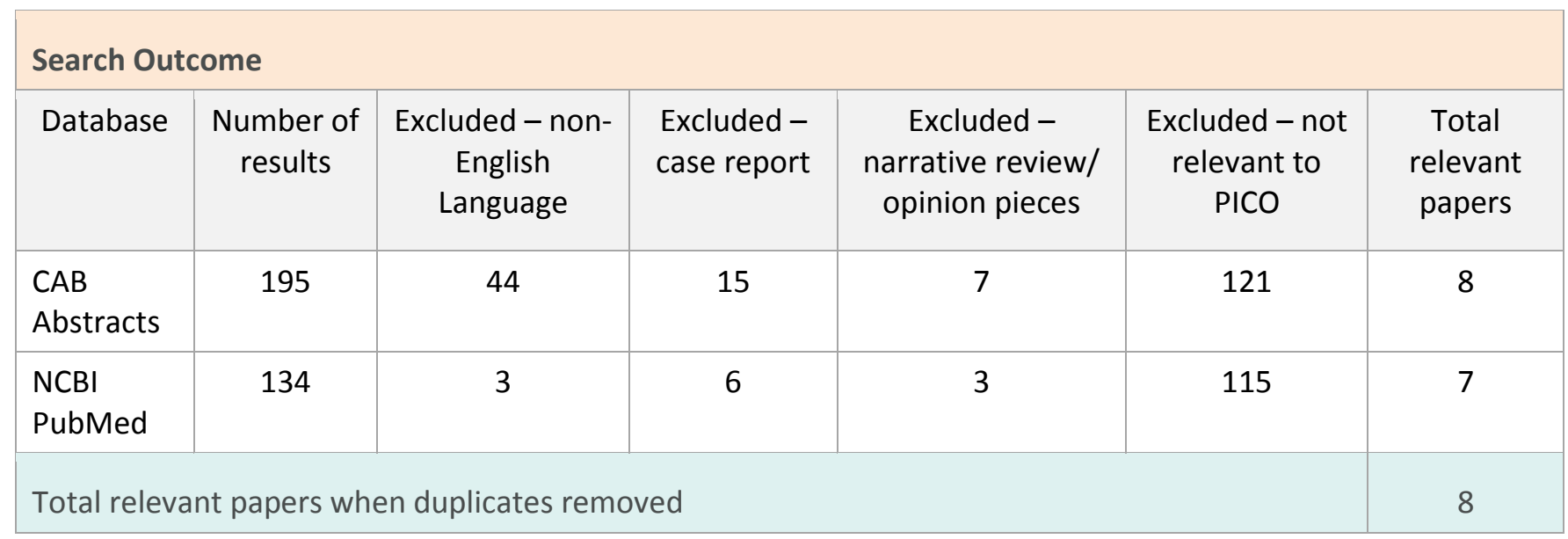

\section{CONFLICT OF INTEREST}

The author declares no conflicts of interest. 


\section{REFERENCES}

1. Golland, L.C., Hodgson, D.R., Hodgson, J.L. et al., (1994) Peritonitis associated with Actinobacillus equuli in horses: 15 cases (1982-1992). Journal of the American Veterinary Medical Association, 205(2), 340-343. Doi: 1111/j.1751-0813.2001.tb10741.x http://europepmc.org/abstract/med/7928617

2. Hawkins J.F., Bowman K.F., Roberts M.C., Cowen P (1993) Peritonitis in horses: 67 cases (19851990). Journal of the American Veterinary Association, 203 (2) 284-

289. http://europepmc.org/abstract/med/8407492

3. Henderson I.S.F, Mair T.S., Keen J.A. et al., (2008) Study of the short- and long-term outcomes of 65 horses with peritonitis. The Veterinary Record, 163, 293-297.

doi:1136/vr.163.10.293 https://www.researchgate.net/publication/23242144 Study of the shortAnd long-term outcomes of 65 horses with peritonitis

4. Javsicas, L.H., Giguere, S., Freeman, D.E., et al., (2010) Comparison of surgical and medical treatment of 49 postpartum mares with presumptive or confirmed uterine tears. Veterinary surgery, 39(2) 254260. doi: 1111/j.1532-950X.2010.00645.x http://onlinelibrary.wiley.com/doi/10.1111/j.1532950X.2010.00645.x/full

5. Matthews, S., Dart, A.J., Dowling, B.A. et al., (2001) Peritonitis associated with Actinobacillus equuli in horses: 51 cases. Australian veterinary journal, 79(8), 536-539. doi: 1111/j.17510813.2001.tb10741.x http://onlinelibrary.wiley.com/doi/10.1111/j.1751-0813.2001.tb10741.x/full

6. Nieto, J.E., Snyder, J.R., Vatistas, N.J. et al., (2003) Use of an active intra-abdominal drain in 67 horses. Veterinary Surgery, 32(1) 1-7. doi: 1053/jvet.2003.50013 http://onlinelibrary.wiley.com/doi/10.1053/jvet.2003.50013/full

7. Nógrádi, N., Tóth, B. and Macgillivray, K. (2011) Peritonitis in horses: 55 cases (2004-2007). Acta Veterinaria Hungarica, 59(2), 181-193. doi: 1053/jvet.2003.50013 http://akademiai.com/doi/abs/10.1556/AVet.2011.011

8. Qadan, M., Dajani, D., Dickinson, A. and Polk Jr, H. C. (2010), Meta-analysis of the effect of peritoneal lavage on survival in experimental peritonitis. British Journal of Surgery, 97: 151-159. doi:10.1002/bjs.6906 http://onlinelibrary.wiley.com/doi/10.1002/bjs.6906/full

9. Schneider, R.K., Meyer, D.J., Embertson, R.M. et al., (1988) Response of pony peritoneum to four peritoneal lavage solutions. American journal of veterinary research, 49(6), 889-

894. http://europepmc.org/abstract/med/3400925 


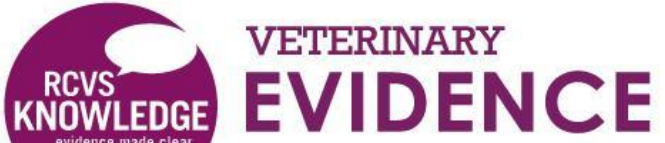 \\ ochese}

\section{Intellectual Property Rights}

Authors of Knowledge Summaries submitted to RCVS Knowledge for publication will retain copyright in their work, and will be required to grant to RCVS Knowledge a non-exclusive license of the rights of copyright in the materials including but not limited to the right to publish, re-publish, transmit, sell, distribute and otherwise use the materials in all languages and all media throughout the world, and to license or permit others to do so.

\section{Disclaimer}

Knowledge Summaries are a peer-reviewed article type which aims to answer a clinical question based on the best available current evidence. It does not override the responsibility

of the practitioner. Informed decisions should be made by considering such factors as individual clinical expertise and judgement along with patient's circumstances and owners' values. Knowledge Summaries are a resource to help inform and any opinions expressed within the Knowledge Summaries are the author's own and do not necessarily reflect the view of the RCVS Knowledge.

Veterinary Evidence and EBVM Network are RCVS Knowledge initiatives. For more information please contact us at editor@veterinaryevidence.org

RCVS Knowledge is the independent charity associated with the Royal College of Veterinary Surgeons (RCVS). Our ambition is to become a global intermediary for evidence based veterinary knowledge by providing access to information

that is of immediate value to practicing veterinary professionals and directly contributes to evidence based clinical decision-making.

www.veterinaryevidence.org

RCVS Knowledge is a registered Charity No. 230886. Registered as a Company limited by guarantee in England and Wales No. 598443.

Registered Office:

Belgravia House

62-64 Horseferry Road

London SW1P 2AF 